\title{
DETERMINATION OF OPTIMAL EXTRACTION PARAMETERS OF POLYPHENOLS FROM FORSYTHIA EUROPAEA DEGEN \& BALD. BLOOM USING RESPONSE SURFACE METHODOLOGY
}

\author{
DANIJELA KOSTIC ${ }^{a *}$, BILJANA ARSIC ${ }^{a}$, MILAN MITIC ${ }^{a}$, \\ SNEŽANA MITIC ${ }^{a}$, MARIJA MARKOVIC ${ }^{b}$, GORDANA, STOJANOVIC ${ }^{a}$
}

\begin{abstract}
The study was designed to examine the influence of ethanol and acetone solvent concentration, extraction time (45-135 min) and extraction technique: maceration and ultrasound extraction on the extraction of total phenolics and flavonoids from petals of Forsythia europaea Degen \& Bald. The highest content of total phenolics in the extracts was obtained using the pure ethanol and acetone in both the extraction processes. The differences in the content of total phenols in different compositions of the mixture for the extraction are the results of different polarities of the applied solvent systems. When ethanol solutions were used for the extraction, the optimum conditions for the extraction of phenols and flavonoids from dried petals by maceration and ultrasound extraction from $F$. europaea were 135 min and $100 \%$ ethanol. In the case of acetone solvent system, the optimum conditions for the extraction by maceration were $135 \mathrm{~min}$ and $98.07 \%$ acetone and for the ultrasound extraction $135 \mathrm{~min}$ and $88.76 \%$ acetone. The optimum conditions for the extraction of flavonoids when the acetone solvent system was used, by maceration and ultrasound extraction were $135 \mathrm{~min}$ and $77.95 \%$ acetone. Obviously, ultrasonic extraction was less time consuming, and it requires for all performed extractions solvent with less percentage of acetone.
\end{abstract}

Keywords: phenolics; flavonoids; maceration; ultrasonic extraction; response surface methodology

\footnotetext{
a University of Nis, Faculty of Sciences and Mathematics, Department of Chemistry, Visegradska 33, 18000 Nis, Serbia

b University of Nis, Faculty of Sciences and Mathematics, Department of Biology, Visegradska 33, 18000 Nis, Serbia

*Corresponding author: danijelaaakostic@yahoo.com
} 
DANIJELA KOSTIC, BILJANA ARSIC, MILAN MITIC, SNEŽANA MITIC, MARIJA MARKOVIC, GORDANA, STOJANOVIC

\section{INTRODUCTION}

Forsythia (Forsithia) is a genus belonging to the olive family (Oleaceae). It is a shrub characteristic by beautiful yellow flowers, but they can be pink for the plant, usually grown in Asia. This genus covers a group of plants originating mainly from Asia (China, Japan), but one species is endemic and grows in the Balkans (Balkan forsythia, lat. Forsythia europaea Degen \& Bald.).

The Balkan or European forsythia (lat. Forsythia europaea Degen \& Bald.) is an endemic species of the Forsythia species whose range of distribution covers northern Albania and areas of the former Yugoslavia. This species is thermophilic and heliophilic, i.e., it requires heat and light.

The fruit of this herb has anti-inflammatory, antipyretic and antiviral properties and is used to treat respiratory infections. It is assumed that it can slow blood coagulation, so it should be avoided before surgery or if a person is already using a drug that has the same effect. Forsythia is not toxic if used in moderation. However, forsythia is not recommended for pregnant women. The list of poisonous plants for pets and humans does not contain forsythia. However, there is a difference between its non-toxicity and edibility. Some people use flowers of forsythia in their diet, but not in large quantities because petals can have a bitter taste.

The flowers of the plant are also used as a salad decoration. It is absolutely safe to have the forsythia in the garden, and it is necessary to find out more about its chemical composition and its effects on humans so that it can be used in nutrition. [1]

There are few scientific papers concerning the testing of this plant species. However, as Forsythia suspensa is used as a plant traditionally in China, there is a need to test its qualitative composition, as it was done by HPLC (Nucleosil C-18 column) analysis with a PDA detector. The methanolic extract was analyzed. The following components were successfully separated by this method: caffeic acid, rutin, forsythoside A, forsythin and forsythigenin. [2]

Phytochemical studies have shown that the major components of this plant, accumulated mainly in the fruit, are triterpenoids, lignans, flavonoids, phenylethanoid glycosides. Studies have shown that phenolic components, including lignans, flavonoids, phenylethanoid glycosides, are responsible for the diverse biological activity of this species. [3] Dried leaves of $F$. europaea collected at Kyoto Herbal Garden in Japan show the presence of the following compounds: phylogenin, (+)-pinorezinol, filirin, (+)-pinorezinol- $\beta-D-$ glucoside, forsitiazide and rutin. [4]

The higher yields in the previous extraction kinetics studies using maceration were achieved by circulation techniques when it was concluded that the operating conditions have an influence on the extraction yield and the kinetics of the extraction. $[5,6]$ 
In the literature, there are no available data on the influence of solvent concentration, extraction time and extraction technique on the quantity of the extracted phenolic compounds from the dried bloom of $F$. europaea.

The $F$. europaea and its extracts can be used as a good source of natural plant pigment and antioxidant agents. Therefore, the aim of this work was the optimization of the extraction process in order to achieve a higher degree of extraction of phenolic compounds from the dried bloom of $F$. europaea.

\section{RESULTS AND DISCUSSION}

In Table 1 it is shown the dependence of the contents of total phenols in ethanol-aqueous extracts of mulberry fruit on time with different concentrations of ethanol-water and acetone-water $(0,50$ and $100 \%)$ of maceration process and ultrasonic extraction. The process lasted 45,90 and $145 \mathrm{~min}$. Total phenol content was shown as mg gallic acid equivalents (GAE) per $100 \mathrm{~g}$ of dried petals.

The phenol content determines the pharmacological properties of the plant and for medicinal plants the concentration of phenol is 0.23 to $2.85 \mathrm{mg}$ GAE / $\mathrm{g}$ fresh sample, while the phenol concentration of culinary plants is 0.26 to $17.51 \mathrm{mg} \mathrm{GAE} / \mathrm{g}$ fresh sample [7]. Based on the literature, the highest content of phenolic compounds is found in culinary herbs of the genus Origanum, about $20 \mathrm{mg} \mathrm{GAE} / \mathrm{g}$ fresh sample. [8]

The content of total phenolics in the tested extracts for maceration and ultrasonic extractions from 479.5 to 2216.2 and 598.33 to $2720.4 \mathrm{mg}$ GAE/100g dried petals, respectively in ethanol-water solvent. The phenol content is low in acetone-water extracts.

In Table 2 it is shown the dependence of the contents of flavonoids in extracts of dried petals on time with different concentrations of ethanol-water and acetone-water $(0,50$ and $100 \%)$ of maceration process and ultrasonic extraction. The process lasted 45,90 and $145 \mathrm{~min}$. Total flavonoid content was shown as $\mathrm{mg}$ catechine equivalents (CE) per $100 \mathrm{~g}$ dried bloom. The content of flavonoid in the tested extracts for maceration and ultrasonic extractions from 454.7 to 2000.5 and 535.5 to $2495.2 \mathrm{mg} \mathrm{CE} / 100 \mathrm{~g}$ dried petals, respectively in ethanol-water extracts. The flavonoid content is low in acetone-water extracts.

Higher content of phenols and flavonoids is in the extracts obtained by ultrasonic extraction. Table 1 . Phenolic content (mg GAE/100g dried petals) 
DANIJELA KOSTIC, BILJANA ARSIC, MILAN MITIC, SNEŽANA MITIC, MARIJA MARKOVIC, GORDANA, STOJANOVIC

Table 1. Phenolic content (mg GAE/100g dried petals)

\begin{tabular}{|c|c|c|c|c|c|c|c|c|c|c|}
\hline & \multicolumn{2}{|l|}{ Water } & \multicolumn{2}{|c|}{ Ethanol 50\% } & \multicolumn{2}{|c|}{ Ethanol $100 \%$} & \multicolumn{2}{|c|}{ acetone $50 \%$} & \multicolumn{2}{|c|}{ acetone $100 \%$} \\
\hline 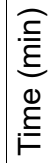 & 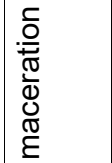 & 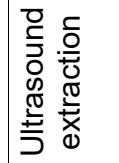 & 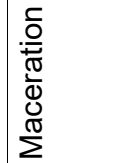 & 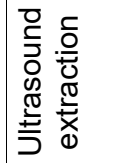 & 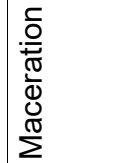 & 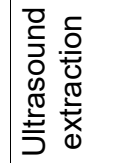 & 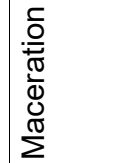 & 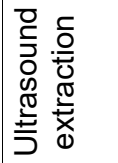 & 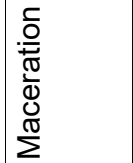 & 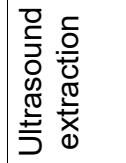 \\
\hline 45 & $\begin{array}{l}479.5 \pm \\
19.60\end{array}$ & $\begin{array}{l}598.3 \pm \\
20.12\end{array}$ & $\begin{array}{l}1287.2 \pm \\
39.615\end{array}$ & $\begin{array}{l}1478.9 \pm \\
15.511\end{array}$ & $\begin{array}{l}1865.5 \pm \\
12.604\end{array}$ & $\begin{array}{l}1515.3 \pm \\
46.111\end{array}$ & $\begin{array}{l}2000 \pm \\
35.51\end{array}$ & $\begin{array}{l}2445.2 \pm \\
42.306\end{array}$ & $\begin{array}{l}\text { 1901.2士 } \\
23.206\end{array}$ & $\begin{array}{l}2258 \pm \\
14.62\end{array}$ \\
\hline 90 & $\begin{array}{l}548.2 \pm \\
20.13\end{array}$ & $\begin{array}{l}682.1 \pm \\
15.06\end{array}$ & $\begin{array}{l}1399.2 \pm \\
41.222\end{array}$ & $\begin{array}{l}1760.5 \pm \\
24.202\end{array}$ & $\begin{array}{l}2187.2 \pm \\
25.302\end{array}$ & $\begin{array}{l}1650.4 \pm \\
51.203\end{array}$ & $\begin{array}{l}2045.3 \pm \\
44.222\end{array}$ & $\begin{array}{l}2600.8 \pm \\
48.905\end{array}$ & $\begin{array}{l}2050.6 \pm \\
26.210\end{array}$ & $\begin{array}{l}2400.3 \pm \\
16.903\end{array}$ \\
\hline 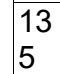 & $\begin{array}{l}591.5 \pm \\
29.24\end{array}$ & $\begin{array}{l}730.5 \pm \\
35.22\end{array}$ & $\begin{array}{l}1503 \pm \\
52.61\end{array}$ & $\begin{array}{l}1889.2 \pm \\
27.803\end{array}$ & $\begin{array}{l}2359.3 \pm \\
24.915\end{array}$ & $\begin{array}{l}1801.2 \pm \\
61.109\end{array}$ & $\begin{array}{l}2216.2 \pm \\
52.312\end{array}$ & $\begin{array}{l}2720.4 \pm \\
60.112\end{array}$ & $\begin{array}{l}2210.5 \pm \\
30.214\end{array}$ & $\begin{array}{l}2605.2 \pm \\
20.604\end{array}$ \\
\hline
\end{tabular}

Table 2. Flavonoids content (mg CE/100g dried petals)

\begin{tabular}{|c|c|c|c|c|c|c|c|c|c|c|}
\hline \multicolumn{3}{|c|}{ Water } & \multicolumn{2}{|c|}{ Ethanol 50\% } & \multicolumn{2}{|c|}{ Ethanol 100\% } & \multicolumn{2}{|c|}{ acetone $50 \%$} & \multicolumn{2}{|c|}{ acetone $100 \%$} \\
\hline 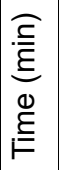 & 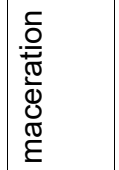 & 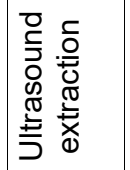 & 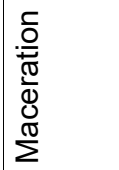 & 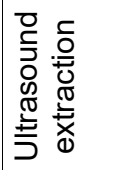 & 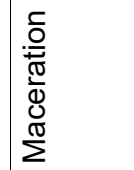 & 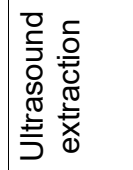 & 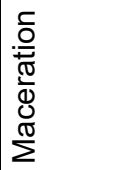 & 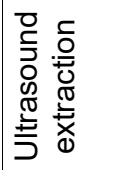 & 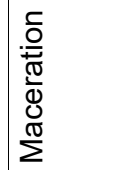 & 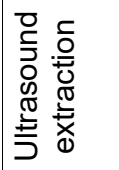 \\
\hline 45 & $\begin{array}{l}485.3 \pm \\
23.22 \\
\end{array}$ & $\begin{array}{l}598.33 \pm \\
20.11 \\
\end{array}$ & $\begin{array}{l}1478.9 \pm \\
15.502 \\
\end{array}$ & $\begin{array}{l}1865.5 \pm \\
12.632 \\
\end{array}$ & $\begin{array}{l}901.2 \pm \\
23.20\end{array}$ & $\begin{array}{l}2258 \pm \\
14.63 \\
\end{array}$ & $\begin{array}{l}1302.2 \pm \\
32.205\end{array}$ & \begin{tabular}{|l}
$1639.8 \pm$ \\
30.501 \\
\end{tabular} & $\begin{array}{l}1352.4 \pm \\
23.601\end{array}$ & $\begin{array}{l}1706.8 \pm \\
25.101 \\
\end{array}$ \\
\hline 90 & $\begin{array}{l}540.5 \pm \\
18.31\end{array}$ & \begin{tabular}{|l|}
$682.12 \pm$ \\
15.06
\end{tabular} & $\begin{array}{l}1760.5 \pm \\
24.211\end{array}$ & $\begin{array}{l}2187.2 \pm \\
25.312\end{array}$ & $\begin{array}{l}2050.6 \pm \\
26.201\end{array}$ & $\begin{array}{l}2400.3 \pm \\
16.904\end{array}$ & $\begin{array}{l}1475.5 \pm \\
33.603\end{array}$ & $\begin{array}{l}1848.8 \pm \\
29.709\end{array}$ & $\begin{array}{l}1506.5 \pm \\
29.303\end{array}$ & $\begin{array}{l}1869.7 \pm \\
26.611\end{array}$ \\
\hline 13 & $\begin{array}{l}591.2 \pm \\
21.12\end{array}$ & $\begin{array}{l}730.51 \pm \\
35.25\end{array}$ & $\begin{array}{l}1889.2 \pm \\
27.803\end{array}$ & $\begin{array}{l}2359.3 \pm \\
24.906\end{array}$ & $\begin{array}{l}2210.5 \pm \\
30.205\end{array}$ & $\begin{array}{l}2605.2 \pm \\
20.603\end{array}$ & $\begin{array}{l}1650.2 \pm \\
36.612\end{array}$ & $\begin{array}{l}2003.2 \pm \\
33.503\end{array}$ & $\begin{array}{l}1612.2 \pm \\
32.805\end{array}$ & $\begin{array}{l}1969.5 \pm \\
32.203\end{array}$ \\
\hline
\end{tabular}

Based on numerous studies, it is known that the content of polyphenolic compounds is influenced by the genotype, site and technique of cultivation, as well as differences in plant maturity.[9] Also, external factors such as light, temperature, the presence of nutrients in the soil, and altitude can affect the phenylpropanoid metabolism of the plant.[10] Phenolic compounds are thought to play the largest role in the biological activity of extracts and their presence contributes to the antioxidant activity of the plant. A large number of studies indicate that the role of flavonoids is of particular importance among phenolic compounds.

Response surface methodology and optimum conditions for the maceration and ultrasound extraction of phenols and flavonoids from dried petals from Forsythia europaea Degen \& Bald. using the ethanol solvent system.

Response surface design and the finding of the optimum conditions for the optimization of maceration were achieved using the software JMP 15 (SAS Institute Inc., Cary, USA). Two factors were selected: time (45 min, 90 $\mathrm{min}$, and $135 \mathrm{~min})$ and percentage of ethanol $(0 \%, 50 \%$, and $100 \%)$. 
The computational modeling of the response surface design and subsequent optimization gives more easily optimized conditions for the extraction of biologically active compounds, such as phenols. Maximum desirability of the extraction process by maceration and ultrasound extraction for the investigated dried petals from $F$. europaea is given in Figure 1, and the pattern in Table 3.
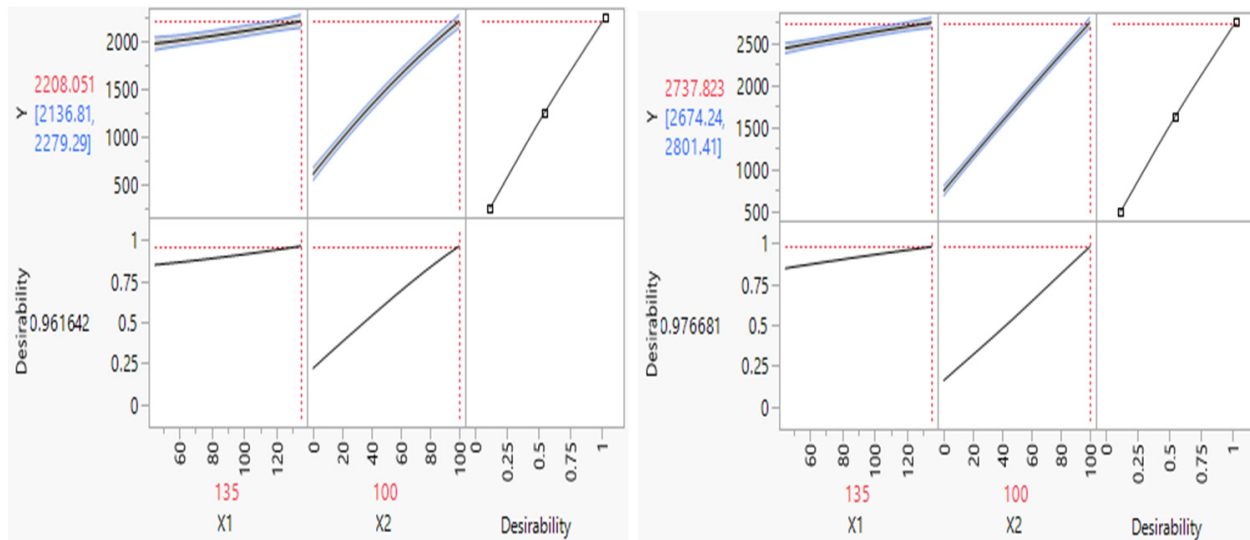

Figure 1. Maximum desirability for the extraction of phenols by maceration and ultrasound extraction using ethanol solvent system

Table 3. Response surface pattern for the extraction of phenols from dried petals of $F$. europaea using ethanol solvent system

\begin{tabular}{|c|c|c|c|c|c|c|c|c|c|}
\hline \multicolumn{9}{|c|}{ Maceration } & \multicolumn{4}{|c|}{ Ultrasound extraction } \\
\hline Pattern & $\begin{array}{c}\text { Time } \\
(\mathrm{min})\end{array}$ & $\begin{array}{c}\text { Ethanol } \\
\%\end{array}$ & $\begin{array}{c}\text { Phenol } \\
\text { content } \\
(\mathrm{mg} \text { GAE/100g } \\
\text { dried petals })\end{array}$ & Pattern & $\begin{array}{l}\text { Time } \\
(\mathrm{min})\end{array}$ & Ethanol\% & $\begin{array}{c}\text { Phenol } \\
\text { content } \\
\text { (mg GAE/100g } \\
\text { dried petals })\end{array}$ \\
\hline 1 & ++ & 135 & 100 & 2216.2 & 1 & 00 & 90 & 50 & 1650.4 \\
\hline 2 & $\mathrm{~A} 0$ & 135 & 50 & 1503 & 2 & $0 A$ & 90 & 100 & 2600.8 \\
\hline 3 & -- & 45 & 0 & 479.5 & 3 & ++ & 135 & 100 & 2720.4 \\
\hline 4 & $0 \mathrm{a}$ & 90 & 0 & 548.2 & 4 & $\mathrm{~A} 0$ & 135 & 50 & 1801.2 \\
\hline 5 & -+ & 45 & 100 & 2000.5 & 5 & $\mathrm{a} 0$ & 45 & 50 & 1515.3 \\
\hline 6 & $0 \mathrm{~A}$ & 90 & 100 & 2045.3 & 6 & -- & 45 & 0 & 598.33 \\
\hline 7 & 00 & 90 & 50 & 1399.2 & 7 & $0 a$ & 90 & 0 & 682.12 \\
\hline 8 & +- & 135 & 0 & 591.5 & 8 & +- & 135 & 0 & 730.51 \\
\hline 9 & 00 & 90 & 50 & 1399.2 & 9 & -+ & 45 & 100 & 2445.2 \\
\hline 10 & $\mathrm{a} 0$ & 45 & 50 & 1287.2 & 10 & 00 & 90 & 50 & 1650.4 \\
\hline
\end{tabular}


The script for the model was run, and the results were displayed with all statistical data. The optimum conditions regarding time and the percentage of ethanol were found using the option of a Prediction profiler and the selection of Maximize Desirability.

The optimum conditions for the extraction of phenols from dried petals by maceration and ultrasound extraction from $F$. europaea were 135 min and $100 \%$ ethanol.

The computational modeling of the response surface design and subsequent optimization gives more easily conditions for the most efficient extraction of biologically active compounds, such as flavonoids. Maximum desirability of the extraction process by maceration and ultrasound extraction for the investigated dried petals from Forsythia europaea Degen \& Bald. is given in Figure 2 and the pattern in Table 4.

The optimum conditions for the maceration and ultrasound extraction of flavonoids from dried petals from $F$. europaea were $135 \mathrm{~min}$ and $100 \%$ ethanol.

Response surface methodology and optimum conditions for the maceration and ultrasound extraction of phenols and flavonoids from dried petals from Forsythia europaea Degen \& Bald. using the acetone solvent system.
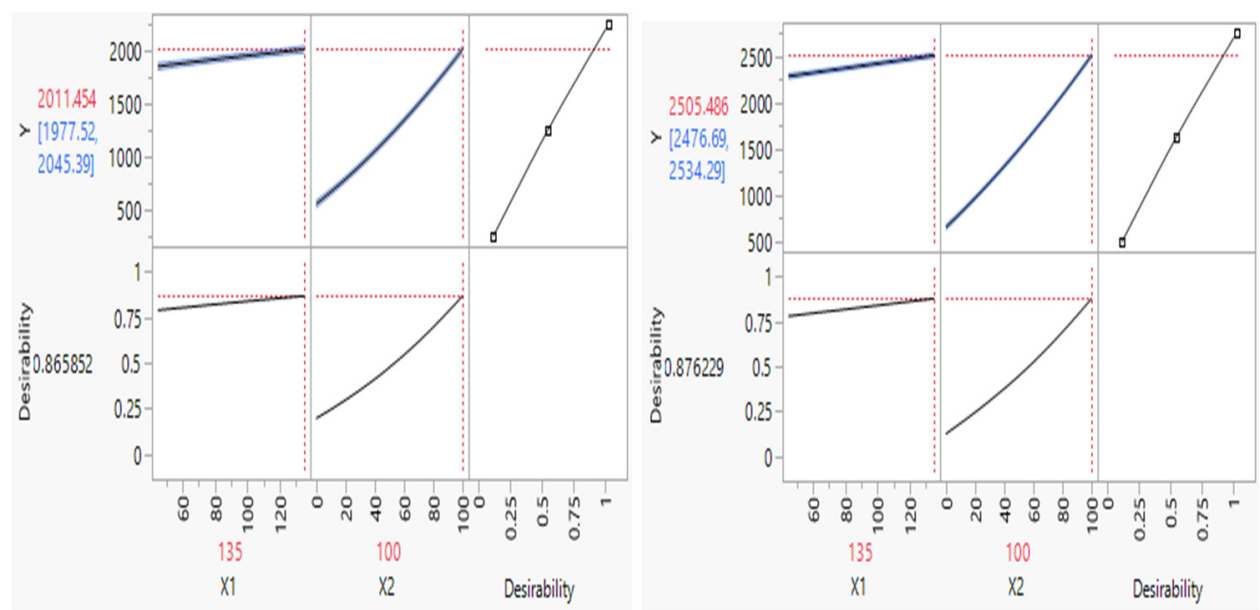

Figure 2. Maximum desirability for the extraction of flavonoids by maceration and ultrasound extraction using ethanol solvent system 
Table 4. Response surface pattern for the extraction of flavonoids by maceration and ultrasound extraction using ethanol solvent system

\begin{tabular}{|c|c|c|c|c|c|c|c|c|c|}
\hline \multicolumn{9}{|c|}{ Maceration } & \multicolumn{4}{|c|}{ Ultrasound extraction } \\
\hline Pattern & $\begin{array}{l}\text { Time } \\
(\mathrm{min})\end{array}$ & Ethanol\% & $\begin{array}{c}\text { Flavonoids } \\
\text { content (mg } \\
\text { CE/100g dried } \\
\text { petals) }\end{array}$ & Pattern & $\begin{array}{c}\text { Time } \\
(\mathrm{min})\end{array}$ & Ethanol\% & $\begin{array}{c}\text { Flavonoids } \\
\text { content } \\
\text { (mg CE/100g } \\
\text { dried petals) }\end{array}$ \\
\hline 1 & 00 & 90 & 50 & 1128.2 & 1 & $0 a$ & 90 & 0 & 590.5 \\
\hline 2 & $0 \mathrm{~A}$ & 90 & 100 & 1942.5 & 2 & 00 & 90 & 50 & 1402.1 \\
\hline 3 & 00 & 90 & 50 & 1128.2 & 3 & 00 & 90 & 50 & 1402.1 \\
\hline 4 & ++ & 135 & 100 & 2000.5 & 4 & -+ & 45 & 100 & 2282.3 \\
\hline 5 & $0 \mathrm{a}$ & 90 & 0 & 502.6 & 5 & +- & 135 & 0 & 655.2 \\
\hline 6 & $\mathrm{~A} 0$ & 135 & 50 & 1212.3 & 6 & -- & 45 & 0 & 535.5 \\
\hline 7 & +- & 135 & 0 & 550.3 & 7 & ++ & 135 & 100 & 2495.2 \\
\hline 8 & -- & 45 & 0 & 454.7 & 8 & $\mathrm{a} 0$ & 45 & 50 & 1311.8 \\
\hline 9 & $\mathrm{a} 0$ & 45 & 50 & 1048.8 & 9 & $\mathrm{~A} 0$ & 135 & 50 & 1508.3 \\
\hline 10 & -+ & 45 & 100 & 1856.2 & 10 & $0 \mathrm{~A}$ & 90 & 100 & 2404.1 \\
\hline
\end{tabular}

Response surface design and the finding of the optimum conditions for the optimization of maceration and ultrasound extraction were achieved using the software JMP 15 (SAS Institute Inc., Cary, USA). Two factors were selected: time ( $45 \mathrm{~min}, 90 \mathrm{~min}$, and $135 \mathrm{~min})$ and percentage of acetone $(0 \%$, $50 \%$, and $100 \%$ ), and one response: the content of phenols obtained by maceration and ultrasound extraction (Table 5 and Figure 3 ).

Table 5. Response surface pattern for the extraction of phenol by maceration and ultrasound extraction using acetone solvent system

\begin{tabular}{|c|c|c|c|c|c|c|c|c|c|}
\hline & Pattern & $\begin{array}{c}\text { Time } \\
\text { (min) }\end{array}$ & Acetone\% & $\begin{array}{c}\text { Phenol } \\
\text { content } \\
\text { (mg GAE/100g } \\
\text { dried petals) }\end{array}$ & Pattern & Time \\
$($ min) & Acetone\% & $\begin{array}{c}\text { Phenol } \\
\text { content } \\
\text { (mg GAE/100g } \\
\text { dried petals) }\end{array}$ \\
\hline 1 & $0 \mathrm{a}$ & 90 & 0 & 540.5 & 1 & ++ & 135 & 100 & 2605.2 \\
\hline 2 & 00 & 90 & 50 & 1760.5 & 2 & +- & 135 & 0 & 730.51 \\
\hline 3 & $0 \mathrm{~A}$ & 90 & 100 & 2050.6 & 3 & -- & 45 & 0 & 598.33 \\
\hline 4 & $\mathrm{~A} 0$ & 135 & 50 & 1889.2 & 4 & 00 & 90 & 50 & 2187.2 \\
\hline 5 & -- & 45 & 0 & 485.3 & 5 & $0 A$ & 90 & 100 & 2400.3 \\
\hline 6 & $\mathrm{a} 0$ & 45 & 50 & 1478.9 & 6 & $\mathrm{a} 0$ & 45 & 50 & 1865.5 \\
\hline 7 & ++ & 135 & 100 & 2210.5 & 7 & $\mathrm{~A} 0$ & 135 & 50 & 2359.3 \\
\hline 8 & -+ & 45 & 100 & 1901.2 & 8 & 00 & 90 & 50 & 2187.2 \\
\hline 9 & 00 & 90 & 50 & 1760.5 & 9 & $0 a$ & 90 & 0 & 682.12 \\
\hline 10 & +- & 135 & 0 & 591.2 & 10 & -+ & 45 & 100 & 2258 \\
\hline
\end{tabular}


DANIJELA KOSTIC, BILJANA ARSIC, MILAN MITIC, SNEŽANA MITIC, MARIJA MARKOVIC, GORDANA, STOJANOVIC
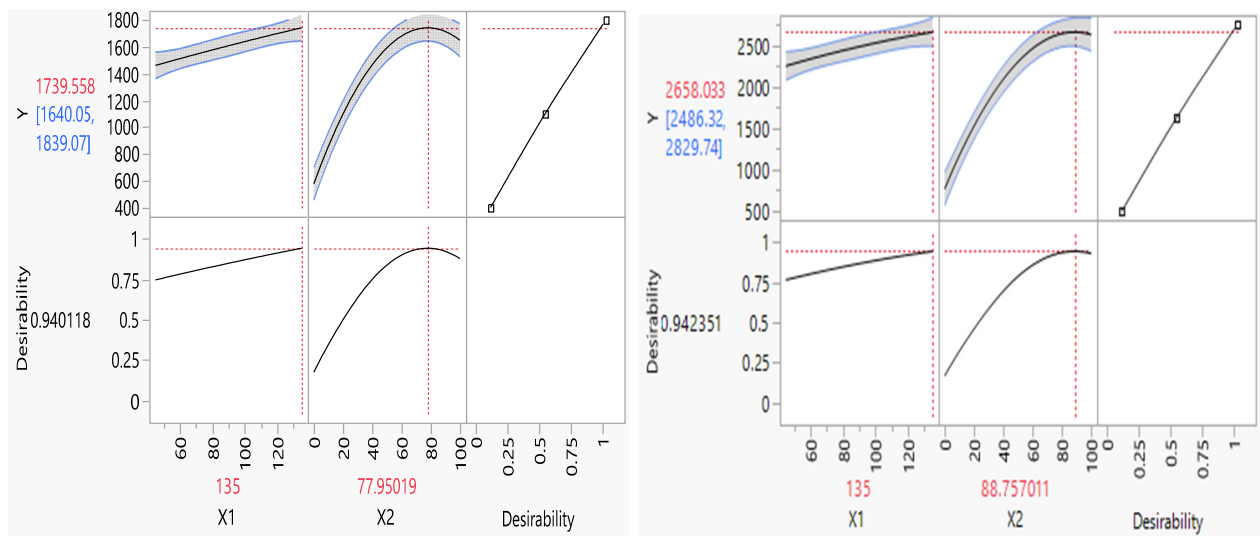

Figure 3. Maximum desirability for the extraction of phenols by maceration and ultrasound extraction using acetone solvent system

The optimum conditions for the extraction of phenols from dried petals from $F$. europaea by maceration were $135 \mathrm{~min}$ and $98.07 \%$ acetone. The optimum conditions for the ultrasound extraction of phenols from dried petals from $F$. europaea were $135 \mathrm{~min}$ and $88.76 \%$ acetone.

Response surface design and the finding of the optimum conditions for the optimization of maceration and ultrasound extraction of flavonoids were achieved using two factors: time (45 min, $90 \mathrm{~min}$, and $135 \mathrm{~min}$ ) and percentage of acetone $(0 \%, 50 \%$, and $100 \%)$, and one response: the content of flavonoids (Table 6 and Figure 4).

Table 6. Response surface pattern for the extraction of flavonoids by maceration and ultrasound extraction using acetone solvent system

\begin{tabular}{|c|c|c|c|c|c|c|c|c|c|}
\hline & Pattern & $\begin{array}{c}\text { Time } \\
(\mathrm{min})\end{array}$ & Acetone\% & $\begin{array}{c}\text { Phenol } \\
\text { content } \\
\text { (mg GAE/100g } \\
\text { dried petals })\end{array}$ & Pattern & $\begin{array}{c}\text { Time } \\
(\mathrm{min})\end{array}$ & Acetone\% & $\begin{array}{c}\text { Phenol } \\
\text { content } \\
\text { (mg GAE/100g } \\
\text { dried petals })\end{array}$ \\
\hline 1 & -- & 45 & 0 & 454.5 & 1 & -+ & 45 & 100 & 1706.8 \\
\hline 2 & ++ & 135 & 100 & 1612.2 & 2 & 00 & 90 & 50 & 1848.8 \\
\hline 3 & $\mathrm{a} 0$ & 45 & 50 & 1302.2 & 3 & $\mathrm{a} 0$ & 45 & 50 & 1639.8 \\
\hline 4 & -+ & 45 & 100 & 1352.4 & 4 & 00 & 90 & 50 & 1848.8 \\
\hline 5 & $\mathrm{~A} 0$ & 135 & 50 & 1650.2 & 5 & $\mathrm{~A} 0$ & 135 & 50 & 2003.2 \\
\hline 6 & $0 \mathrm{~A}$ & 90 & 100 & 1506.5 & 6 & ++ & 135 & 100 & 1969.5 \\
\hline 7 & $0 \mathrm{a}$ & 90 & 0 & 501.5 & 7 & -- & 45 & 0 & 535.5 \\
\hline 8 & 00 & 90 & 50 & 1475.5 & 8 & +- & 135 & 0 & 655.2 \\
\hline 9 & +- & 135 & 0 & 550.7 & 9 & $0 \mathrm{~A}$ & 90 & 100 & 1869.7 \\
\hline 10 & 00 & 90 & 50 & 1475.5 & 10 & $0 \mathrm{a}$ & 90 & 0 & 590.5 \\
\hline
\end{tabular}




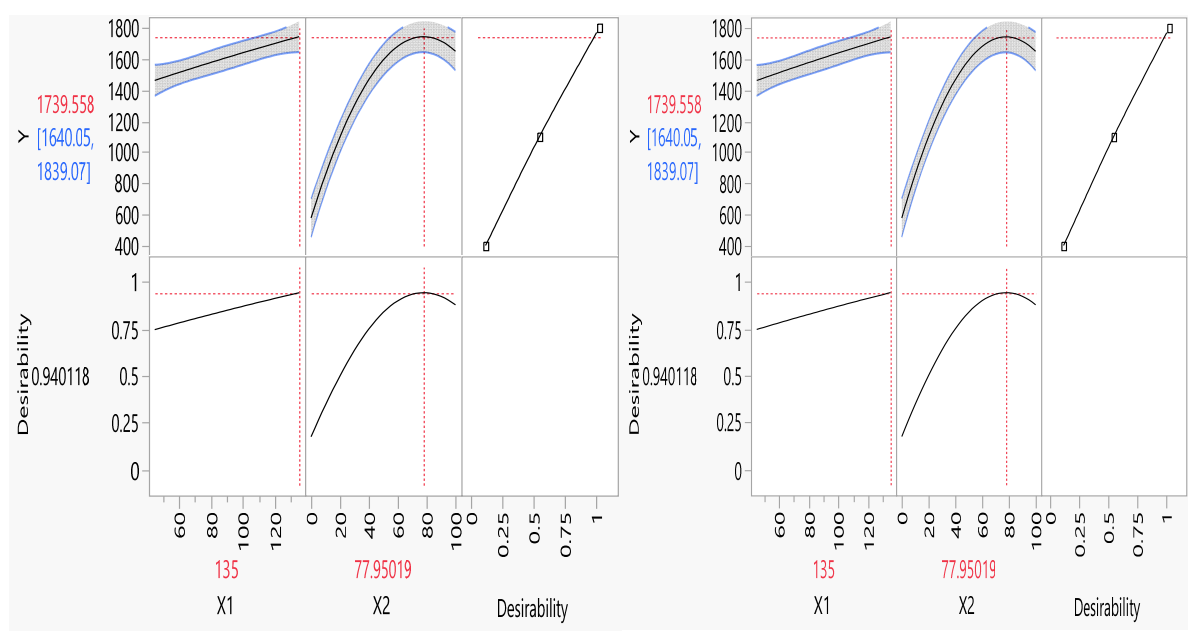

Figure 4. Maximum desirability for the extraction of flavonoids by by maceration and ultrasound extraction using acetone solvent systemThe optimum conditions for the extraction of flavonoids from dried petals from $F$. europaea by maceration and ultrasound extraction were identical $135 \mathrm{~min}$ and $77.95 \%$ acetone.

In our previously study we examined the influence of solvent concentration, extraction time and extraction technique on the extraction yield of phenolic compounds, flavonoids and antioxidant activity from Morus nigra L., Morus rubra L. and Morus alba L. fruits. The best conditions for the extraction of total phenols, flavonoids and monomeric anthocyanins by the maceration and ultrasonic extraction processes were found. [11] Obviously, ultrasonic extraction was less time consuming, and it requires for all performed extractions smaller percentage of solvent.

\section{CONCLUSIONS}

Contents of total phenols and flavonoids in extracts of dried bloom from $F$. europaea on time with different concentrations of ethanol and acetone $(0$, 50 and $100 \%$ ) by maceration process and ultrasonic extraction. The content of total phenolics in the tested extracts for maceration and ultrasonic extractions from 479.5 to 2216.2 and 598.33 to $2720.4 \mathrm{mg}$ GAE/100 g dried petals, respectively in ethanol-water extracts. The content of flavonoid in the tested extracts for maceration and ultrasonic extractions from 454.7 to 200.5 
and 535.5 to $2495.2 \mathrm{mg} \mathrm{CE} / 100 \mathrm{~g}$ dried petals, respectively in ethanol water extracts. The phenols and flavonoid content are low in acetone-water extracts. Higher content of phenols and flavonoids is in the extracts obtained by ultrasonic extraction.

The highest content of total phenolics in the extracts obtained using the pure ethanol and acetone in both the extraction process. The differences in the content of total phenols in different compositions of the mixture for extraction are the result of different polarity of the applied solvent systems. The optimum conditions for the extraction of phenols and flavonoids from dried petals by maceration and ultrasound extraction from $F$. europaea were 135 min and $100 \%$ ethanol.

The optimum conditions for the extraction of phenols from dried petals from Forsythia europaea Degen \& Bald. by maceration was 135 min and 77.95 $\%$ acetone. The optimum conditions for the ultrasound extraction of phenols from dried petals from $F$. europaea was 135 min and $88.76 \%$ acetone.

The optimum conditions for the extraction of flavonoids from dried petals from $F$. europaea by maceration and ultrasound extraction were 135 min and $77.95 \%$ acetone.

The results show that the effect of ultrasound has a positive effect on the rate of extraction of phenolic compounds. The results indicate a high content of phenolic compounds F. europaea located in Southeast Serbia, which confirms their nutritional and pharmacological potential of this plant.

\section{EXPERIMENTAL SECTION}

Material: The petals of the Balkan Forsythia plant harvested from the Nis area (Cair Park) in March 2016 were used for this work. The plant was identified and recorded in the herbarium of the Faculty of Natural Sciences and Mathematics in Niš and was given a voucher number 11982 (Forsithia europaea Degen \& Bald, 11982)

Apparatus and reagents: An Agilent 8453 UV-vis spectrophotometer (USA) was used for the absorbance measurements and spectra recording, using an optical or quartz cuvettes of $1 \mathrm{~cm}$ optical path. The $\mathrm{pH}$ measurements were made with Hanna Instruments pH-meter (USA) equipped with the glass electrode. The Folin-Ciocalteu phenol reagent and sodium carbonate were purchased from Merck Chemical Suppliers (Darmstadt, Germany). The other used chemicals including solvents were of analytical grade. 
Maceration: Homogenized dried bloom and milled $(2 \mathrm{~g})$ was soaked into the mixture of the previously prepared solvent: ethanol-water $(0 \%, 50 \%, 100 \%)$, aceton-water $(0 \%, 50 \%, 100 \%)$, at a ratio of $1: 50 \mathrm{w} / \mathrm{v}$. Maceration with a solvent system was performed at 45,90 or $135 \mathrm{~min}$ at $25^{\circ} \mathrm{C}$. The suspension was then filtered through a Buchner funnel and Whatman No.1 filter paper. The extracts were stored in the refrigerator and in the dark to their further use for the determination of phenolic compounds. [12]

Ultrasonic extraction: Milled plant material $(2 \mathrm{~g})$ was extracted with the previously mentioned solvent systems in the thermostatic ultrasonic bath (Sonic, Niš, Serbia) with the nominal power: $3 \times 50 \mathrm{~W}$; dimensions of bathrooms: $30 \times 15 \times 20 \mathrm{~cm}$, and at a frequency of $40 \mathrm{kHz}$. The kinetics of the extraction of phenolic compounds were collected at the indicated time intervals (45-135 minutes). The extracts were separated from the plant material on Buchner's funnel with a weak vacuum and further treated according to the procedure for the determination of total phenols. [13]

Determination of total phenolics: Total phenol contents of the extracts were found by the modified Folin-Ciocalteu method. An aliquot of the extracts $(1 \mathrm{~mL})$ was mixed with $0.5 \mathrm{~mL}$ Folin-Ciocalteu reagent and $2 \mathrm{~mL}$ of sodium carbonate $(20 \%)$. The absorbance was recorded after $10 \mathrm{~min}$ of the incubation at room temperature at $760 \mathrm{~nm}$. The total phenolic content was expressed as $\mathrm{mg} / 100 \mathrm{~g}$ gallic acid equivalent (GAE). The result of each assay was obtained from 3 parallel determinations. [14]

Determination of total flavonoid content Total flavonoid content was determined using a spectrophotometric method based on the formation of flavonoid complex with aluminum. Total flavonoid content was calculated as catechin (mg CE/100g) using the equation based on the calibration curve. [15]

Response surface methodology and optimum conditions for the extraction: Response surface design and the finding of the optimum conditions for the optimization of maceration and ultrasonic extractions were achieved using the software JMP 14.0.1 (SAS Institute Inc., Cary, USA) [16] Two factors were selected: time (45 min, $90 \mathrm{~min}, 145 \mathrm{~min}$ ) and \% ethanol $(0 \%, 50 \%$, and $100 \%)$, acetone $(0 \%, 50 \%$, and $100 \%)$, and three responses: total phenols, flavonoids, and the Central Composite Design with 2 central points. The script for the model was run, and the results were displayed with all statistical data. The optimum conditions regarding time and the solvent system were found using the option of Prediction profiler and the selection of Maximize Desirability. The average value of the optimum time and the solvent system was found from three measurements. 
DANIJELA KOSTIC, BILJANA ARSIC, MILAN MITIC, SNEŽANA MITIC, MARIJA MARKOVIC, GORDANA, STOJANOVIC

\section{ACKNOWLEDGMENTS}

The authors acknowledge the Ministry of Education, Science and Technological Development of Serbia for the financial support 451-03$68 / 200124$

\section{REFERENCES}

1. Q. Zhang C; Jia H.; Xu Y.; Wang M.; Zhang C.; Huo Q.; S Shi; Z. Yu; Mini-Rev. Org. Chem., 2012, 9(3),303-318(16).

2. Y.Y. Cui; S.Y. Feng; G. Zhao; M.Z. Wang; Yao. Xue. Xue. Bao., 1992, 27(8), 603-608.

3. B. Yang; A. Kotani; K. Arai; F. Kusu; Anal. Sci., 2001,17, 599-604.

4. S. Kitagawa; S. Nishibe; R. Benecke; H. Thieme; Chem. Pharm. Bull. 1988, 36(9), 3667-3670.

5. D. Milenovic; V. Veljkovic; T. Todorovic; M. Stankovic; Chem. Ind. 2002, 56(2), 54-60.

6. Lj. P. Stanojević; M.Z. Stanković; M.D. Cakić; V.D. Nikolić; Lj. B. Nikolić; D.P. Ristić; Chem. Ind., 2009, 63, 79-86.

7. W. Zheng; S.Y. Wang; J. Agricul. Food Chem., 2001, 49(11), 5165-5170.

8. G. Cervato; M. Carabelli; S. Gervasko; A. Cittera; R. Cazzola; C. Benvenuto; J. Food Biochem. 2000, 24(6), 453-465.

9. D. Orhan; A. Hartevioğlu; E. Küpeli; E. Yesilada ; J. Ethnopharm., 2007, 112,394-400.

10. R.A. Dixon; N.L. Paiva; Plant Cell. 1995, 7, 1085-1097.

11. E. Kostić; B. Arsić; M. Mitić; D. Dimitrijević; E. Pecev Marinkovic; Not. Bot. Horti. Agrobot. Cluj Napoca, 2019, 47(3),629-633.

12. J.R. Dean; Extraction techniques in analytical sciences (Vol. 34). John Wiley \& Sons, Ltd. 2009.

13. M. Vinatoru; Ultrason. Sonochem. 2015, 25, 94-95.

14. V.L. Singleton; J.A. Rossi; Am. J. Enol. Viticul. 1965,16(3),144-158.

15. B. Stojanovic; S. Mitic; G. Stojanovic; M. Mitic; D. Kostic; D. Paunovic; B. Arsic, Not. Bot. Horti. Agrobot. Cluj Napoca. 2016, 44(1), 175-182.

16. W. Mietlowski; J. Biopharm. Stat. 2008, 18(3), 590-594 